ARKADIUSZ LEWANDOWSKI

Instytut Politologii UMK

\title{
Akcja Wyborcza „Solidarność” - prawica zjednoczona, prawica rozbita
}

\section{Uwagi wstępne}

ybory parlamentarne w roku 1997 były okresem przełomowym dla
ugrupowań szeroko pojmowanej polskiej centroprawicy'. System partyjny budowany w III Rzeczypospolitej podlegał ciągłej ewolucji ujawniającej się w przemianach partii politycznych. Specyfika tworzenia się ugrupowań wywodzących się z opozycji demokratycznej sprawiła, iż przechodziły one nienaturalną drogę rozwoju. Efektem takiego procesu była nie tylko słabość instytucjonalna, ale również znaczna liczba konkurujących ze sobą ugrupowań o podobnym charakterze ideowym.

Jak się okazało, rywalizacja w ramach demokratycznych wyborów wymagała o wiele większej zdolności współpracy, aniżeli czasy kontestacji systemu. Pierwszym egzaminem z tych umiejętności była elekcja parlamentarna w roku 1993, kiedy po zastosowaniu instytucji progu wyborczego

Jako cechy prawicy należałoby uznać: popieranie wolnej przedsiębiorczości, obniżenia podatków oraz ograniczenia roli państwa w gospodarce, popieranie tradycji narodowych, sceptycyzm wobec integrowania się ze strukturami międzynarodowymi, przywiązanie do idei ładu i porządku publicznego, poparcie dla Kościoła, optowanie za surowym karaniem przestępców. Zob. A. Antoszewski, Prawica, w: Leksykon politologii, red. A. Antoszewski, R. Herbut, Wrocław 2004, s. 339. 
w ramach ordynacji wyborczej ${ }^{2}$ okazało się, iż liderom prawicy zabrakło talentu politycznego.

Szansę na rehabilitację dawały wybory w 1997 roku. Współpraca polityków była konieczna, ponieważ została utrzymana instytucja progu wyborczego oraz znowelizowano sposób finansowania partii politycznych z budżetu państwa na podstawie ustawy o partiach politycznych z 27 czerwca $1997 \mathrm{roku}^{3}$. Niezdobycie mandatu poselskiego wiązało się z co najmniej czteroletnią, jeżeli nie dożywotnią, polityczną banicją. Co prawda, dwa ukazane powyżej czynniki wpłynęły na stabilizację polskiego systemu partyjnego, ale jednocześnie mogły okazać się politycznie śmiertelne w skutkach dla wielu ugrupowań i ich liderów, którzy nie dojrzeli do zdolności koncyliacyjnych, i nie zdążyli na czas stworzyć silnych koalicji wyborczych.

Wobec takich przesłanek, proces łączenia się prawicy przed wyborami z 1997 roku wydawał się nie tyle naturalny, co wręcz konieczny. Tylko w taki sposób możliwe było osiągnięcie wyniku na poziomie $30 \%{ }^{4}$, który z kolei pozwalał na odsunięcie od władzy Sojuszu Lewicy Demokratycznej.

Niniejszy artykuł stanowi próbę odpowiedzi na pytanie, czy twór polityczny, jaki stanowiła AWS, rzeczywiście tworzył jednolity blok prawicowy, czy też może od początku był skazany na rozpad, a wizje kreacji jednolitej partii politycznej nigdy nie miały realnego charakteru?

\section{Tendencje zjednoczeniowe środowisk prawicowych przed wyborami 1997 roku}

Zakończone porażką centroprawicy wybory roku 1993 sprawiły, iż jedynie sześć komitetów wyborczych (z czego tylko dwa: KPN z wynikiem 5,8\% oraz BBWR - 5,4\% należałoby uznać za prawicowe) posiadało reprezentantów w Sejmie, co stanowiło znaczące zmniejszenie liczby podmiotów parlamentarnych w stosunku do elekcji wcześniejszej (28 ugrupowań). Przegrane wybory były efektem między innymi błędów taktycznych popełnionych przez liderów ugrupowań prawicowych oraz ich niewiedzy na temat konse-

\footnotetext{
Zagadnienie ewolucji ordynacji wyborczej zostało opisane: M. Migalski, Wpływ ordynacji wyborczych na kształtowanie sie polskiego systemu partyjnego, w: M. Mazur, M. Migalski, W. Wojtasik, Polski system partyjny, Warszawa 2006, s. 56-78.

3 Zob. W. Wojtasik, Status prawny partii politycznych $w$ Polsce, w: M. Mazur, M. Migalski, W. Wojtasik, dz. cyt., s. 25-29.

$4 \quad$ Według Wiesławy Jednakiej, jak również Antoniego Dudka, w całej dekadzie lat 90. XX wieku poparcie dla ugrupowań centroprawicowych, które w 1997 roku znalazły się w ramach Akcji Wyborczej „Solidarność”, oscylowało wokół podobnego poziomu 30\%. Zob. W. Jednaka, Wybory parlamentarne 1989-2001, w: Demokratyzacja w III Rzeczypospolitej, red. A. Antoszewski, Wrocław 2002, s. 90; A. Dudek, Wystapienie podczas konferencji Prawica w Polsce 19892005, w: Prawica w Polsce 1989-2005, red. M. Migalski, Katowice 2005, s. 8-11.
} 
kwencji nowej ordynacji ${ }^{5}$. Po raz pierwszy bowiem zastosowano ordynację wyborczą z 5\% klauzulą zaporową dla partii politycznych (dla koalicji wyborczych wynosiła ona 8\%, zaś dla listy krajowej 7\%). Bezpośrednim efektem takiego mechanizmu wyborczego było pozbawienie aż 34,6\%, tj. 4769901 wyborców własnej reprezentacji parlamentarnej ${ }^{6}$. Problem ten dotyczył szczególnie małych i konkurujących ze sobą ugrupowań prawicowych.

Paradoksalnie jednak - jak zauważa Ryszard Terlecki - reprezentanci prawicy, głosując za pięcioprocentowym progiem wyborczym, sami przyczynili się do swej porażki. Celem ich działania było pozbycie się drobniejszych prawicowych konkurentów. Nikt wówczas nie dbał o elektorat, a standardem stały się kłótnie i podejrzenia o samą ,"prawicowość” konkurentów ${ }^{7}$.

Zaskakujące jest, że porażka wyborcza roku 1993 przyniosła pewne korzystne rezultaty. Nieudana batalia wpłynęła pozytywnie na środowiska prawicowe, które zaczęły „profesjonalnie” myśleć o rywalizacji politycznej. Moim zdaniem, wybory roku 1993 można uznać za pierwszy krok w kreowaniu się zjednoczeniowych tendencji $\mathrm{w}$ prawicowym nurcie politycznym. Uważam, że na ich „scalenie” nie wpłynęła tylko klęska wyborcza, ale także wyciągnięcie wniosków z własnych błędów, tj.: niewykreowania wspólnego kandydata w wyborach prezydenckich roku 1995 (w konsekwencji wygrał postkomunistyczny polityk Aleksander Kwaśniewski) oraz braku skutecznej sygnalizacji politycznych problemów i potrzeb licznych grup społecznych, spowodowanej nieobecnością ich reprezentantów w parlamencie.

Ostatni z problemów ujawnił się między innymi podczas procesu tworzenia nowej ustawy zasadniczej. Już na początku II kadencji sejmu, pod patronatem NSZZ „Solidarność”, została powołana Społeczna Komisja Konstytucyjna pod przewodnictwem Mariana Krzaklewskiego, która zamierzała opracować własny projekt konstytucji. Zbieranie pod nim podpisów, rozpoczęte w marcu 1994 roku, zakończyło się sukcesem. Uzyskano 1,5 mln głosów poparcia. I choć Komisja Konstytucyjna Zgromadzenia Narodowego zignorowała ten projekt ${ }^{8}$, osiągnięcie to pokazało, jaką siłą może dysponować nie tylko związek, ale zjednoczona prawica.

Marek Migalski dodaje jeszcze jedną, jak się wydaje, bardzo ważną przyczynę przegranej ugrupowań prawicowych, a mianowicie powołanie przez prezydenta Lecha Wałęsę pod hasłem „osłabiania prawej nogi” Bezpartyjnego Bloku Wspierania Reform, który być może odebrał brakujące głosy takim ugrupowaniom, jak: PC, ZChN, KLD oraz "Solidarność". M. Migalski, Wpływ ordynacji wyborczych na ksztattowanie się polskiego systemu partyjnego, s. 69-70.

6 A. Dudek, Historia polityczna Polski 1989-2005, Kraków 2007, s. 268-269.

$7 \quad$ R. Terlecki, Prawa wolna, w: Spór o Polskę, red. P. Śpiewak, s. 279.

8 E. Dubertowa, Od drużyny Lecha Wałęsy do Akcji Wyborczej Solidarność, Poznań 2005, s. 67-68. 
Te oto wydarzenia - uzupełnione rządami koalicji wyborczej Sojuszu Lewicy Demokratycznej oraz Polskiego Stronnictwa Ludowego - wymusiły niejako proces łączenia się sił prawicowych. W warunkach braku pełnej możliwości „artykułowania” politycznych propozycji, cenne stawało się tworzenie dużego ugrupowania, które nie tylko bezproblemowo przekraczałoby próg wyborczy, ale mogłoby śmiało starać się o zwycięstwo w kolejnych wyborach. Kazimierz M. Ujazdowski w pracy, stanowiącej wezwanie do jednoczenia się prawicy, Prawica dla wszystkich pisał następująco: „Arytmetyka wyborów 1993 roku jest jednoznaczna: są tylko dwie wielkie siły polityczne zdolne ubiegać się o władzę. Posiadające aparat, środki finansowe, wpływy $\mathrm{w}$ administracji stronnictwa postkomunistyczne i rozbita, uboga, ale mająca potencjał poparcia wystarczający do zwycięstwa wyborczego prawica"'. Naturalnym zatem jest, że ugrupowania prawicowe, pozostające poza parlamentem, podjęły kilka prób integracji, tworząc: Konwent Św. Katarzyny, Porozumienie 11 Listopada, Przymierze dla Polski, Sekretariat Ugrupowań Centroprawicowych ${ }^{10}$.

Jako pierwszy z wyżej wymienionych powstał - utworzony w październiku 1993 roku z inicjatywy Jarosława Kaczyńskiego - Sekretariat Ugrupowań Centroprawicowych (SUC). W jego skład wchodziły partie tworzące wspólną listę wyborczą z Porozumieniem Centrum: Ruch Trzeciej Rzeczypospolitej, Chrześcijańsko Demokratyczne Stronnictwo Pracy, Stronnictwo Wierności Rzeczypospolitej, Porozumienie Regionalne Ruchu dla Rzeczypospolitej oraz Porozumienie Ludowe. Jednak nowy twór polityczny rozpadł się bardzo szybko. Po niepowodzeniu próby nawiązania współpracy ze Zjednoczeniem Chrześcijańsko-Narodowym Sekretariat opuściły: PC oraz $\mathrm{PL}^{11}$.

Działalność SUC-u polegała na prezentowaniu wspólnego dla jego członków stanowiska wobec wydarzeń politycznych oraz organizowaniu konferencji tematycznych z udziałem organizacji centroprawicowych (poruszano tematy dotyczące gospodarki, samorządu czy wychowania młodzieży) ${ }^{12}$.

W 1993 roku powstał także drugi ośrodek współpracy partii prawicowych, a mianowicie: Porozumienie 11 listopada. Współzałożycielami były między innymi takie ugrupowania, jak: Unia Polityki Realnej, Partia Konser-

K. M. Ujazdowski, Prawica dla wszystkich, Warszawa 1995, s. 18.

10 M. Migalski, Polska, w: Partie i systemy partyjne państw Europy Środkowej i Wschodniej, red. tenże, Sosnowiec 2005, s. 226.

11 Zob. A. Dudek, Historia polityczna..., s. 304.

12 K. A. Paszkiewicz, Sekretariat Ugrupowań Centroprawicowych, w: Partie i koalicje polityczne III Rzeczypospolitej, red. taż, Wrocław 2004, s. 240. 
watywna, Partia Chrześcijańsko-Demokratyczna, Stronnictwo LudowoChrześcijańskie i Stronnictwo Narodowo-Demokratyczne. Struktura ta przetrwała jednak tylko do stycznia 1995 roku, kiedy to nastąpił ostateczny rozpad porozumienia ${ }^{13}$.

„Najpoważniejszą próbę budowania samodzielnej prawicy” według Kazimierza M. Ujazdowskiego stanowiło Przymierze dla Polski powstałe w wyniku współpracy Jarosława Kaczyńskiego oraz Wiesława Chrzanowskiego (liderów PC oraz ZChN-u) ${ }^{14}$. Zawarty 9 maja 1994 roku sojusz mieścił w swoich szeregach oprócz dwóch głównych ugrupowań także: Porozumienie Ludowe, Ruch dla Rzeczypospolitej (R. Szeremietiewa ${ }^{15}$ ) oraz Koalicję Konserwatywną. Jednak jeszcze przed rozpoczęciem właściwych działań integracyjnych Przymierze dla Polski zaczęło się rozpadać ${ }^{16}$. Przyczyną tego procesu był, według Antoniego Dudka, konflikt między Kaczyńskim a Szeremietiewem o kierunek rozszerzenia stronnictwa oraz napięcia wewnątrz ZChN-u (konflikt dotyczył prezydenta Lecha Wałęsy) ${ }^{17}$. Zupełnie inny powód rozpadu Przymierza dla Polski podaje uczestnik tamtych wydarzeń, Kazimierz M. Ujazdowski. Według niego, kością niezgody był wybór kandydata do wyborów prezydenckich ${ }^{18}$.

Jeszcze przed rozpadem Przymierza dla Polski udało się zawrzeć porozumienie w styczniu 1995 roku o współpracy z Porozumieniem 11 listopada, w ramach którego opracowano Wspólne Zasady Programowe ${ }^{19}$, jednak ostatecznie cały projekt zakończył się niepowodzeniem.

Problem wyłonienia jednego kandydata całej prawicy w wyborach prezydenckich był pretekstem do uformowania się jeszcze jednej inicjatywy w pewnym sensie ją integrującej. W listopadzie 1994 roku po raz pierwszy odbyło się spotkanie przedstawicieli ugrupowań centroprawicowych (nazwane Konwentem Św. Katarzyny), które latem 1995 podjęły się wyłonienia

13 A. Dudek, Historia polityczna..., s. 306.

14 K. M. Ujazdowski, dz. cyt., s. 41.

15 Ugrupowanie, które odłączyło się od Ruchu dla Rzeczypospolitej. Przyczyną były różnice zdań w sprawie zawarcia porozumienia z organizacjami popierającymi Lecha Wałęsę. Na kongresie w grudniu 1993 wybrano na stanowisko przewodniczącego partii Romualda Szeremietiewa, z czym nie zgodzili się głosujący na dotychczasowego przewodniczącego Jana Olszewskiego: popierający jego koncepcje współpracy z NSZZ „Solidarność”. Od 3 lutego 1996 roku grupa Szeremietiewa nosiła nazwę Ruch dla Rzeczypospolitej-Obóz Patriotyczny. B. Sawicka, Ruch dla Rzeczypospolitej-Obóz Patriotyczny, w: Partie $i$ koalicje polityczne III Rzeczypospolitej, s. 121, 124.

16 A. Dudek, Historia polityczna..., s. 306.

17 Tamże, s. 307.

18 Zob. K. M. Ujazdowski, dz. cyt., s. 47.

19 Zob. K. A. Paszkiewicz, Przymierze dla Polski, w: Partie i koalicje polityczne III Rzeczypospolitej, s. 238. 
wspólnego kandydata w nadchodzących wyborach prezydenckich. Obrady te doprowadziły jednak do konfliktu pomiędzy zwolennikami kandydatur Hanny Gronkiewicz-Waltz oraz Jana Olszewskiego. W efekcie, na konwencie nie doszło do porozumienia. Różnica zdań nie dotyczyła jedynie wspólnego kandydata na urząd Prezydenta Rzeczypospolitej Polskiej. Spór odnosił się również do innych kwestii, między innymi kształtu integracji prawicy: Jarosław Kaczyński opowiadał się za rozwiązaniem wszystkich ugrupowań i powołaniem w ich miejsce jednej partii, z kolei Ryszard Czarnecki, ówczesny przewodniczący $\mathrm{ZChN-u,} \mathrm{był} \mathrm{zwolennikiem} \mathrm{utworzenia} \mathrm{federacji} \mathrm{już} \mathrm{istniejących}$ stronnictw ${ }^{20}$.

Ostateczny sygnał do integracji ugrupowań postsolidarnościowych dało - przeprowadzone w lutym 1996 roku - referendum w sprawie uwłaszczenia. Główną siłą polityczną w tej grze był NSZZ „Solidarność”, który zorganizował spotkanie przedstawicieli dwunastu partii i ruchów społecznych w celu zajęcia jednolitego stanowiska wobec pytań zawartych w referendum. Powołano wspólny Komitet Poparcia Referendum Uwłaszczeniowego ${ }^{21}$. Okazało się, iż spośród pięciu pytań, jakie zostały postawione w ramach referendum, tylko odpowiedź na jedno z nich wywołała spór pomiędzy prezydentem Kwaśniewskim i Unią Wolności a środowiskami centroprawicy. Ostatecznie liczba odpowiedzi na „tak” w czterech pytaniach dotyczących kwestii popieranych przez obie strony wynosił od 88 do 94,5\% głosów. Natomiast wobec proponowanego przez centroprawicę sprzeciwu dla propozycji rozszerzenia programu NFI udało się osiągnąć wynik tylko 27,5\% głosów na „tak”. Oznaczało to, iż 72,5\% biorących udział w referendum głosowało zgodnie z sugestiami „Solidarności”, ROP-u, ZChN-u KPN-u oraz innych ugrupowań prawicowych ${ }^{22}$. Skala poparcia nie mogła pozostać niezauważona przez polityków, którzy zrozumieli, że tylko połączone siły centroprawicy mogły przynieść zwycięstwo w najbliższych wyborach. „Surowe lekcje”, jakimi okazały się wybory parlamentarne roku 1993 oraz wybory prezydenckie w roku 1995, nie mogły pójść na marne.

Warto podkreślić wzrastające znaczenie „Solidarności” w obrębie centroprawicowych ugrupowań politycznych, które nie mogły dojść porozumienia z powodu waśni liderów, różnic programowych oraz odmiennych idei jednoczenia prawicy. Umożliwiło to sytuację, w której kierowana przez Mariana Krzaklewskiego „Solidarność” stała się podstawową siłą polityczną, skupiającą wokół siebie ugrupowania centroprawicowe. Wpływ na taki bieg

$20 \quad$ K. Knyżewski, Partie $i$ system partyjny $w$ Polsce $w$ okresie transformacji ustrojowej, Warszawa 1998, s. 120-121.

$21 \quad$ E. Dubertowa, dz. cyt., s. 77.

22 A. Dudek, Historia polityczna..., s. 336-337. 
wydarzeń miała zapewne „słabość i marginalizacja znaczenia” ${ }^{23}$ dotychczasowych stronnictw oraz coraz silniejsza „Solidarność". Zapewne nie bez znaczenia były dwumilionowa rzesza członków związku oraz zaplecze organizacyjne i finansowe ${ }^{24}$.

\section{Powstanie Akcji Wyborczej „Solidarność”}

Przedstawione powyżej próby integrowania środowisk centroprawicowych nie powiodły się. Sukcesem okazała się dopiero inicjatywa pod auspicjami NSZZ „Solidarność”, która, jak pokazuje chociażby casus referendum uwłaszczeniowego, stała się głównym podmiotem integracyjnym.

8 czerwca 1996 podpisano deklarację o powołaniu Akcji Wyborczej „Solidarność". Formalnie zaś za datę powstania koalicji przyjmuje się dzień 11 lipca, kiedy to organy statutowe poszczególnych ugrupowań ratyfikowały deklarację $^{25}$. Pod inicjatywą Związku podpisały się m.in.: Zjednoczenie Chrześcijańsko-Narodowe, Ruch dla Rzeczypospolitej, Ruch dla Rzeczypospolitej-Obóz Patriotyczny, Ruch „Solidarni w Wyborach”, Konfederacja Polski Niepodległej (zarówno frakcje Adama Słomki, jak i Leszka Moczulskie$\mathrm{go}^{26}$ ), Porozumienie Centrum, Ruch Stu, Solidarni w Wyborach, Nowa Polska, Stronnictwo Polityki Realnej, Prawica Narodowa, ChrześcijańskoDemokratyczne Stronnictwo Pracy, Stronnictwo Narodowo-Demokratyczne, Polskie Stronnictwo Ludowe (Mikołajczykowskie), Partia Konserwatywna, Niezależne Zrzeszenie Studentów, Stronnictwo Demokracji Polskiej, Instytut Lecha Wałęsy. Ostateczne ukształtowanie się AWS-u nastąpiło 10 października 1996 roku. Do istniejącej już koalicji swój akces zgłosiły takie partie, jak: Polska Federacja Stowarzyszeń Rodzin Katolickich, Polska Partia Ekologiczna

23 L. Graniszewski, Akcja Wyborcza Solidarność - sojusz prawicy demokratycznej, w: Wybory'97. Partie i programy wyborcze, s. 60.

24 Tamże, s. 60.

25 Pomysł utworzenia właśnie takiej struktury jak AWS padł podczas konferencji programowej „Solidarności” na Uniwersytecie Warszawskim, podczas której profesor Jadwiga Staniszkis zaproponowała utworzenie Akcji Wyborczej NSZZ „Solidarność”. M. Krzaklewski, Fragment książki M. Krzaklewski, Czas na Akcję. Marian Krzaklewski w rozmowie z Maciejem Łętowskim i Piotrem Zaremba, „Tygodnik AWS” 1997, nr 37, s. 10.

26 Rozpad na dwa ugrupowania nastąpił 10 lutego, kiedy to nową partię, to jest Konfederację Polski Niepodległej-Obóz Patriotyczny (Ojczyzna) powołali członkowie związani z Adamem Słomką. Była to odpowiedź na wybór Leszka Moczulskiego na siódmą z rzędu kadencję przewodniczącego partii. Głównym zarzutem wobec historycznego lidera ugrupowania była jego niechęć wobec odmładzania kadr ugrupowania oraz utrzymywanie partii w stagnacji. B. Sawicka, Konfederacja Polski Niepodległej - Ojczyzna (Obóz Patriotyczny), w: Partie i koalicje polityczne III Rzeczypospolitej, s. 39. 


\section{RP}

Zieloni, Koalicja Konserwatywna, Bezpartyjny Blok Wspierania Reform, Ruch Opcji Ludowo-Agrarnych „ROLA”27.

Ze względu na tak szeroką koalicję oraz nierównomierne rozmiary poszczególnych ugrupowań konieczne stało się ustalenie podziału głosów w głównym organie koalicyjnym, czyli Radzie Krajowej AWS- $u^{28}$. Dominującym podmiotem stała się związkowa „Solidarność, która otrzymała 50\% udziałów. Po 5\% uzyskały PC oraz ZChN. Nieco poniżej 5\%: KPN (Moczulskiego), Federacja Rodzin Katolickich oraz Ruch Stu. Nieco poniżej 4\% zdobyły: KPN (Słomki), BBWR - Solidarni w Wyborach, Niezależne Zrzeszenie Studentów. Pozostałe ugrupowania uzyskały wpływ nieprzekraczający $2 \%$ głosów ${ }^{29}$.

Rada Krajowa na swojego przewodniczącego wybrała Mariana Krzaklewskiego. Zastępcami zostali natomiast: Janusz Tomaszewski („S”), Marian Piłka (ZChN), Adam Słomka (KPN) oraz Kazimierz Kapera (Polska Federacja Stowarzyszeń Rodzin Katolickich) ${ }^{30}$.

Problemy z mobilnością funkcjonowania Rady Krajowej oraz jej organu wykonawczego, czyli Zespołu Koordynacyjnego spowodowały, iż w kwietniu 1998 roku Rada powołała swoje prezydium, które przyjęło za cel poszukiwanie kompromisu w ważnych dla AWS-u sprawach. Zadaniem członków prezydium było reprezentowanie AWS-u w kontaktach z rządem oraz $\mathrm{w}$ relacjach $\mathrm{z} \mathrm{UW}^{31}$.

Ugrupowanie - w związku z nadchodzącymi wyborami parlamentarnymi - ogłosiło własny program polityczny w maju 1997 roku. Podstawą dla dokumentu była Karta AWS-u, która stanowiła fundament programowy dla uczestnictwa w koalicji.

Sam polityczny program koalicji wyborczej rozpoczynał się od wstępu ukazującego podstawowy cel, jaki stawia sobie Akcja, czyli budowę „Prawej Polski" z silną rodziną i odpowiednim miejscem w Europie ${ }^{32}$. Właśnie bezpieczeństwo rodziny wraz z ideą społecznej solidarności jako wyznacznikiem

27 K. A. Paszkiewicz, Akcja Wyborcza „Solidarność”, w: Partie i koalicje polityczne III Rzeczypospolitej, s. 224.

28 Był to organ stanowiący oraz kontrolujący działalność AWS-u. Kierował nim przewodniczący wybierany przez członków Rady Krajowej. Władzą wykonawczą był zaś Zespół Koordynacyjny. K. A. Paszkiewicz, Akcja Wyborcza..., s. 231. Szczegółowo na temat struktury władz AWS-u oraz organów terenowych, w: L. Graniszewski, dz. cyt., s. 72-75.

29 E. Dubertowa, dz. cyt., s. 80. W marcu 1997 roku, po utworzeniu Stronnictwa Konserwatywno-Ludowego ugrupowanie to dołączyło do grona partii posiadających największy wpływ w Radzie Krajowej AWS-u. A. Dudek, Historia polityczna..., s. 339.

30 E. Dubertowa, dz. cyt., s. 79.

31 Zob. W. Załuska, Wysokie prezydium, „Gazeta Wyborcza” 1998, nr 89, s. 4.

32 Program Akcji Wyborczej Solidarność, w: Wybory 1997. Partie i ich programy, red. I. Składkowska, Warszawa 2004, s. 102. 
działań w życiu społecznym oraz gospodarczym stały się podstawą programu AWS-u ${ }^{33}$.

Pierwsza część dokumentu została poświęcona rodzinie, która stanowić powinna podstawę całego społeczeństwa. Naród określony został jako „rodzina rodzin”, zaś podstawę ładu Rzeczypospolitej widziano w prawie naturalnym, w tym: w prawie do życia od poczęcia do naturalnej śmierci ${ }^{34}$.

Odpowiedni poziom życia rodzin zapewnić miały: rozwój budownictwa, tworzenie nowych miejsc pracy, reforma służby zdrowia, ubezpieczeń społecznych oraz edukacji. Równocześnie, poruszono kwestię ochrony dziedzictwa narodowego, które według autorów, wpływało na kształtowanie nowoczesnego Polaka.

Drugim elementem programu było zagadnienie nowoczesnej gospodarki. Politycy AWS-u za jej fundamenty uznawali własność prywatną oraz mechanizmy rynkowe, jednak, jak zaznaczali, przeobrażenia muszą dokonać się przy akceptacji głównych sił społecznych. Według programu, należało ograniczyć funkcję państwa jako właściciela i centralnego regulatora gospodarki. Rola państwa miała polegać zaś na tworzeniu warunków rozwoju gospodarczego. Planowano unowocześnić rolnictwo opierające się na gospodarstwach rodzinnych oraz restrukturyzacji kluczowych branż przemysłu.

W dalszej części dokument dotyczył kwestii silnego i bezpiecznego państwa. W tym celu proponowano: gruntowną przebudowę administracji państwa, stworzenie profesjonalnej służby cywilnej oddzielonej od polityki, przeprowadzenie lustracji, usprawnienie sądownictwa, reformę prokuratury, przywrócenie pluralizmu w mediach, reformę i profesjonalizację policji oraz służb specjalnych, a także modernizację wojska. Silnie akcentowana była również potrzeba rozbudowy (o jeszcze jeden stopień) samorządu terytorialnego, gospodarczego oraz zawodowego.

Ostatnie zagadnienie poruszone w programie to sprawy międzynarodowe. Pojawiły się deklaracje o dążeniach do stworzenia zjednoczonej Europy wolnych narodów jako Europy Ojczyzn oraz optowanie za jak najszybszym wstąpieniu Polski do NATO.

Uzupełnienie programu stanowił - przedstawiony w sierpniu 1997 roku - „Plan dla Polski XXI wieku”, zawierający 21 punktów, które w zasadzie powielały kwestie przedstawione w programie $\mathrm{e}^{35}$.

Pismem Akcji Wyborczej „Solidarność” był „Tygodnik AWS” - wydawnictwo o charakterze tygodnika społecznego. Na jego łamach nie odbywała

$33 \quad$ K. A. Paszkiewicz, Akcja Wyborcza..., s 225.

34 Analiza programu AWS-u na podstawie tekstu z: Program Akcji Wyborczej „Solidarność, s. $102-108$.

35 Zob. M. Krzaklewski, 21 postulatów w XXI wiek, „Gazeta Wyborcza” 1997, nr 211, s. 22. 
się dyskusja programowa czy też ideowa. Poruszane były w nim raczej sprawy bieżące, opisujące rzeczywistość. Każdy z numerów składał się z politycznych komentarzy (autorstwa m.in. Aleksandra Halla, Krzysztofa Piesiewicza, Macieja Iłowieckeigo czy Macieja Rybińskiego), aktualności oraz wywiadów z politykami. Swoje felietony publikowali w nim przedstawiciele świata nauki i kultury, jak chociażby: Ryszard Legutko, Marek Mankowicz, Marek Oramus. Istniały również działy: Kraj, Świat, Społeczeństwo oraz Gazeta Akademicka.

Większość ugrupowań centroprawicowych z szeregów AWS-u osiągnęło względny kompromis. Pojawił się symptom procesu jednoczenia: składająca się z blisko 40 ugrupowań, klubów i stowarzyszeń Akcja, stawała się koalicją pięciu udziałowców AWS-u. Duża w tym zasługa Mariana Krzaklewskiego, który podjął się działań konsolidacyjnych ${ }^{36}$. Warto jednak zwrócić uwagę na fakt, iż proces „scalania” poszczególnych udziałowców Akcji przebiegał dość szybko, a linia podziałów przebiegać zaczęła w oparciu o różnice ideowe, które stawały się łącznikiem dla poszczególnych ugrupowań. Było to ważne, gdyż kluczowym elementem, jaki pozwolił odnieść sukces AWS-owi, było funkcjonowanie jako bardzo szeroka koalicja ideowa ${ }^{37}$. Koalicja, której podmioty łączyły się na bazie minimum programowego, ujętego w Karcie AWS-u.

Od samego początku istnienia Akcji, a w szczególności po sukcesie wyborczym, pojawiały się również koncepcje przemiany koalicji w jednolitą partię polityczną ${ }^{38}$. Tendencje te były jednak równoważone przez zwolenników wykonania jedynie kroku pośredniego, jaki miało stanowić powołanie struktury federacyjnej ${ }^{39}$.

\section{Ruchy scaleniowe wewnątrz AWS-u}

Jednym z pierwszych procesów „scaleniowych”, i jak się później okazało, jednym z ważniejszych wewnątrz Akcji, było powstanie Stronnictwa Konserwatywno-Ludowego w dniu 12 stycznia 1997 roku. Nowe ugrupowanie to wynik integracji Partii Konserwatywnej, Stronnictwa LudowoChrześcijańskiego oraz grupy byłych członków Unii Wolności z Janem Rokitą

\section{A. Dudek, Wystapienie podczas konferencji..., s. 10.}

37 Największe triumfy podczas wyborów odniosły nurty: chrześcijańsko-narodowy oraz konserwatywny, nie licząc oczywiście związkowego. K. Szymański, AWS jako metoda polityczna, „Debata" 1998, nr 3, s. 37.

38 W. Załuska, Federacja to pułapka. Rozmowa z Kazimierzem M. Ujazdowskim, „Gazeta Wyborcza” 1997, nr 269, s. 6.

39 Tenże, Prawica bez balastu. Rozmowa z Aleksandrem Hallem, „Gazeta Wyborcza” 1998, nr 236, s. 7. 
na czele ${ }^{40}$. Sami założyciele postrzegali to „scalenie” jako szansę na zjednoczenie nowoczesnej prawicy wolnorynkowej, respektującej prawicowy kanon wartości ${ }^{41}$.

Parlamentarny okres integrowania się grup politycznych w ramach AWS-u trwał do lipca 1999 roku. Rozpoczął się zaraz po wyborach, kiedy to w grudniu 1997 r. powołano do życia Ruch Społeczny AWS-u (największe wówczas ugrupowanie polityczne w Akcji), który miał pełnić funkcję partyjnej reprezentacji związku zawodowego ${ }^{42}$. W późniejszym okresie, gdy tendencje zjednoczeniowe nasilały się, do Ruchu Społecznego przyłączyły się: PSL-Porozumienie Ludowe, RdR-Obóz Patriotyczny, Nowa Polska, Stowarzyszenie Rodzin Katolickich i Liga Krajowa ${ }^{43}$. Ruch Społeczny wraz z „Solidarnością" stanowiły jeden z podstawowych związkowych nurtów Akcji.

Drugi fundament AWS-u tworzyli konserwatyści początkowo skupieni w SKL-u oraz Koalicji Konserwatywnej. Próba „scalenia” całego nurtu konserwatywno-liberalnego - prowadzona od początku 1998 roku przez SKL nie skończyła się pełnym sukcesem. Udało się mu połączyć jedynie z Koalicją Konserwatywną, co miało miejsce 21 lutego 1999 roku. Na pewno zwiększyło to siłę konserwatystów wewnątrz Akcji, co zauważyli i próbowali wykorzystać sami zainteresowani ${ }^{44}$.

Trzecim dominującym nurtem było środowisko $\mathrm{ZChN-u,} \mathrm{które} \mathrm{od} \mathrm{po-}$ czątku kadencji starało się utrzymać stały skład osobowy oraz własne wpływy reprezentujące skrzydło narodowe w Akcji.

Oprócz wymienionych powyżej trzech głównych nurtów prawicy istniało jeszcze czwarte - najpóźniej zintegrowane - środowisko chrześcijańsko-demokratyczne. Do września 1999 roku funkcjonowało ono w Akcji jako Zespół Chrześcijańsko-Demokratyczny powołany przez Porozumienie Centrum oraz Partię Chrześcijańskich Demokratów (później z tychże dwóch ugrupowań powstało Porozumienie Polskich Chrześcijańskich Demokratów $)^{45}$.

Trwający tylko półtora roku proces scalania się centroprawicowych ruchów politycznych doprowadził do utworzenia pięciu sił politycznych

40 K. Paszkiewicz, Stronnictwo Konserwatywno-Ludowe, w: Partie i koalicje polityczne III Rzeczypospolitej, s. 173.

41 A. Hall, Stało się, „Przegląd Konserwatywny” 1997, s. 5.

42 A. Dudek, Historia polityczna..., s. 367.

43 W. Załuska, Gdybym ja miał trzy nogi, „Gazeta Wyborcza” 1999, nr 20, s. 7.

${ }_{44}$ M. D. Zdort, O jedna partię mniej, „Rzeczpospolita” 1999, nr 27, s. 2; tenże, Konserwatyści bliscy zjednoczenia, „Rzeczpospolita” 1998, nr 258, s. 3; W. Załuska, A rokoszan pędzić, „Gazeta Wyborcza" 1999, nr 44, s. 6.

45 Zob. K. A. Paszkiewicz, Porozumienie Centrum, w: Partie i koalicje polityczne III Rzeczypospolitej, s. 106-107. M.D. Zdort, O jedna partię mniej, „Rzeczpospolita” 1999, nr 27, s. 2. 
wewnątrz koalicji. Wymuszało to jednak zmiany w sposobie zarządzania Akcją, która przestała być zlepkiem ugrupowań, a stała się prawdziwą koalicją coraz to silniejszych, a co zatem idzie, silniej konkurujących ze sobą „komponentów". Dostrzegały one swoją siłę, dlatego też zmierzały ku zmianom organizacyjnym wewnątrz federacji.

Pierwszym przejawem zmian było utworzenie sześcioosobowego zespołu w ramach Klubu Parlamentarnego AWS-u, który miał podejmować najważniejsze decyzje polityczne. Postanowienie to stanowiło sukces zarówno SKL-u jak i ZChN-u, które dążyły do wyrównania sił w Akcji. W składzie zespołu zasiadać mieli: Marian Krzaklewski (szef NSZZ „Solidarność”, honorowy przewodniczący RS AWS-u), Jerzy Buzek (lider RS AWS), Jacek Rybicki (przewodniczący Rady Politycznej RS AWS), Marian Piłka (prezes ZChN-u), Mirosław Styczeń (prezes SKL-u) i Paweł Łączkowski (lider Zespołu Chrześcijańsko-Demokratycznego ${ }^{46}$.

Od tego czasu, wewnątrz Akcji trwały negocjacje na temat nowego kształtu ugrupowania. Środowiska niezwiązkowe dążyły do ograniczenia siły przedstawicieli związku do poziomu poniżej 50\% głosów w Radzie Krajowej. Ostateczne decyzje zapadły podczas Rady Krajowej AWS-u w Gdańsku w dniu 29 lipca 1999 roku. Postanowiono, iż liderem AWS-u nie będzie już „automatycznie” szef NSZZ „Solidarność", ale ponownie powołano na to stanowisko Mariana Krzaklewskiego. Zdecydowano również o nowym podziale głosów wewnątrz Rady. Zmniejszono pulę głosów związkowców z 50\% do 48\% („Solidarność" 25\%, RS AWS 23\%). Pozostałe partie (SKL, ZChN i PC-PChD) otrzymały po $16 \%$. Ostatnie $4 \%$ podzieliły między siebie akcyjne stowarzyszenia (między innymi Liga Krajowa) oraz „małe partie”. Rada postanowiła również, iż decyzje podejmowane będą większością 55\%, w przypadku natomiast decyzji personalnych i dotyczących zmian w statucie AWS-u wymagana będzie większość $75 \%$ głosów ${ }^{47}$.

\section{Akcja Wyborcza „Solidarność” w rządzie koalicyjnym i w parlamencie}

Wybory roku 1997 były starciem pomiędzy dwiema koalicjami wyborczymi: Centroprawicową Akcją Wyborczą „Solidarność” oraz lewicowym Sojuszem Lewicy Demokratycznej ${ }^{48}$. Dzięki wygranej oraz zdobyciu 202 manda-

\footnotetext{
46 Zob. W. Załuska, Superprezydium Akcji, „Gazeta Wyborcza” 1999, nr 55, s. 6.

47 Zob.: tenże, Ile komu władzy w AWS, „Gazeta Wyborcza” 1999, nr 149, s. 6; tenże, Koalicja pięciu formacji, „Gazeta Wyborcza” 1999, nr 154, s. 4; R. Kalukin, W. Załuska, Pięciu udziałowców Akcji, „Gazeta Wyborcza” 1999, nr 176, s. 4.

48 Listę dziesięciu komitetów wyborczych zarejestrowanych w całym kraju uzupełniły: Unia Pracy, Blok dla Polski (utworzony z koalicji BBWR, Stronnictwa Narodowego oraz Polskiej
} 
tów poselskich oraz 51 senatorskich, członkowie „Solidarności” zaczęli stanowić najwększy zespół parlamentarny. Jednak układ sił politycznych w nowym parlamencie nie sprzyjał szybkiej kreacji nowego gabinetu. Odrzucając jeszcze przed wyborami, w fazie kampanii wyborczej, możliwość współpracy dwóch największych ugrupowań (AWS i SLD), liderzy partyjni AWS-u nie negowali opcji żadnego innego układu koalicyjnego ${ }^{49}$.

Przez pierwszy tydzień po wyborach lider Akcji Marian Krzaklewski prowadził rozmowy w sprawie utworzenia koalicji z ROP-em oraz PSL-em. Dopiero później rozpoczęły się rozmowy z Unią Wolności. Prawdopodobne jest, iż rozpatrywanie tworzenia rządu przez AWS wraz z ROP-em oraz PSLem było jedynie rozgrywką polityczną ukierunkowaną na „zmiękczenie” postawy $\mathrm{UW}^{50}$. Na rezygnację z koncepcji tworzenia „antyliberalnego” gabinetu trzech ugrupowań miał wpływ zapewne fakt, iż taka koalicja nie posiadałaby znaczącej większości głosów w Sejmie, co, w połączeniu z dużym zróżnicowaniem wewnątrz samego AWS-u, byłoby wielkim ryzykiem dla nowo utworzonego rządu ${ }^{51}$.

Negocjacje pomiędzy Akcją Wyborczą „Solidarność” oraz Unią Wolności trwały ponad miesiąc (cały proces formowania się rządu liczony od dnia wyborów do dnia desygnowania Jerzego Buzka na urząd premiera zajął 53 dni) i zakończyły się podpisaniem umowy koalicyjnej pomiędzy obydwoma ugrupowaniami na czas kadencji Sejmu. Ciekawostką jest, iż rozmowy nie były toczone przez liderów ugrupowań, a jedynie przez delegowanych przez nich polityków ${ }^{52}$. W pośredni sposób na proces tworzenia kolacji wpływał również prezydent Kwaśniewski, który po spotkaniu z Marianem Krzaklewskim we wrześniu 1997 roku zasugerował, iż chciałby w pierwszym dniu obowiązywania nowej konstytucji (tj. 17 października) desygnować nowego premiera $^{53}$.

Unii Właścicieli Nieruchomości), Krajowa Partia Emerytów i Rencistów, Krajowe Porozumienie Emerytów i Rencistów Rzeczypospolitej Polskiej, Unia Wolności, PSL (Mikołajczykowskie), Unia Prawicy Rzeczypospolitej (była to koalicja drobnych ugrupowań prawicowych pod przewodnictwem Unii Polityki Realnej) oraz Ruch Odbudowy Polski. A. Piasecki, Wybory parlamentarne, samorzadowe prezydenckie 1989-2002, Toruń 2004, s. 76

49 Tamże, s. 79.

50 Zob. W. Jednaka, Gabinety koalicyjne w III RP, Wrocław 2004, s. 183.

51 D. Kawa, J. Marszłałek-Kawa, Rząd Jerzego Buzka, w: Rządy koalicyjne w III RP, red. M. Chmaj, Olsztyn 2006, s. 194.

52 Ze strony AWS-u prowadzili je: Janusz Tomaszewski, Marek Kempski, Romuald Kukułowicz, Tomasz Tywonek, Jerzy Buzek, i Paweł Łączkowski. Natomiast ze strony UW: Tadeusz Syryjczyk, Bogdan Borusewicz, Janusz Onyszkiewicz, Jan Lityński, Jan Król oraz Marek Komorowski. A. Dudek, Historia polityczna..., s. 354.

53 W. Jednaka, Gabinety koalicyjne..., s. 185. kształtowania koalicji zob. tamże, s. 182-197; K. Leszczyńska, Rzady Rzeczypospolitej w latach 1989-2001: skład, organizacja i tryb funkcjonowania, Toruń 2006, s. 85-91. 
11 listopada 1997 roku sejm 260 głosami posłów „za” (przy 172 „przeciwko" oraz dwóch wstrzymujących się od głosowania) udzielił wotum zaufania gabinetowi Jerzego Buzka. Kształt polityczny rządu został określony przez umowę koalicyjną. Wicepremierami zostali: Leszek Balcerowicz - finanse (UW) oraz Janusz Tomaszewski - sprawy wewnętrzne i administracja (AWS). Z desygnacji AWS-u resorty objęli: Wiesław Walendziak - Kancelaria Prezesa Rady Ministrów, Emil Wąsacz - Ministerstwo Skarbu Państwa, Janusz Pałubicki - koordynator służb specjalnych, Janusz Steinhoff - Ministerstwo Gospodarki, Longin Komołowski - Ministerstwo Pracy i Polityki Socjalnej, Mirosław Handtke - Ministerstwo Edukacji Narodowej, Jacek Janiszewski - Ministerstwo Rolnictwa i Gospodarki Żywnościowej, Eugeniusz Maksymowicz - Ministerstwo Zdrowia i Opieki Społecznej, Teresa Kamińska - Reformy Społeczne, Ryszard Czarnecki - Komitet Integracji Europejskiej, Jerzy Kropiwnicki - Rządowe Centrum Studiów Strategicznych, Marek Zdrojewski -Ministerstwo Łączności, Jan Szyszko - Ministerstwo Ochrony Środowiska, Zasobów Naturalnych i Leśnictwa, Andrzej Wiszniewski - Komitet Badań Naukowych, Jerzy Widzyk - minister ds. usuwania skutków powodzi ${ }^{54}$.

Ostatecznie rząd tworzony był przez 23 polityków, z czego 17 desygnowała Akcja, natomiast 6 - Unia Wolności. Z kolei w dniu składania dymisji przez rząd, Rada Ministrów składała się z 18 osób ${ }^{55}$. Jedynie trzej ministrowie utrzymali swoje posady przez cały okres rządów. Byli to: Janusz Steinhoff, Andrzej Wiszniewski oraz Longin Komołowski. Wynikało to ze sposobu funkcjonowania koalicji rządowej. Rząd J. Buzka nie należał bowiem do działających sprawnie i bezkonfliktowo ${ }^{56}$. Wpływ na taki stan rzeczy miały nie tylko trudne relacje pomiędzy koalicjantami, ale również formuła samego AWS-u, która jako koalicja wyborcza nie ustrzegła się konfliktów wewnętrznych.

Napięta sytuacja w koalicji rządowej stała się immanentnym elementem funkcjonowania rządu J. Buzka. Konflikty pomiędzy ugrupowaniami miały charakter zarówno merytoryczny (między innymi sprzeciw UW wobec przeprowadzenia czterech reform od razu), jak również personalny (np. konflikt pomiędzy J. Kropiwnickim a L. Balcerowiczem). Zażegnanie sporów miały spowodować zmiany personalne w składzie rządu przeprowadzone w roku $1999^{57}$. Wyjściem z kryzysowych sytuacji miał być również podpisany

\footnotetext{
A. Dudek, Historia polityczna..., s. 355.

K. Leszczyńska, dz. cyt., s. 95.

56 O funkcjonowaniu koalicyjnego rządu oraz rządu mniejszościowego pod przewodnictwem J. Buzka zob. G. Rydlewski, Rządzenie koalicyjne w Polsce, Warszawa 2000, s. 45-64; W. Jednaka, Gabinety koalicyjne..., s. 246-264.

57 Dokonano wówczas sześciu zmian na czele ministerstw: kultury, łączności, rolnictwa, zdrowia, spraw wewnętrznych i administracji oraz ochrony środowiska. Zlikwidowano
} 
w październiku 1999 roku aneks do umowy koalicyjnej. Oprócz kwestii programowych związanych z walką z korupcją, a w szczególności z reformą podatkową, zawarto w nim precyzyjne zasady wspólnego działania w koalicji oraz w parlamencie ${ }^{58}$.

Jak pokazała historia, starania te nie pomogły przetrwać koalicji. o jej końcu przesądziło wprowadzenie przez premiera zarządu komisarycznego w gminie Warszawa Centrum zarządzanej przez koalicję UW oraz SLD. Następstwem tego działania była decyzja zarządu Unii Wolności z 22 maja 2000 roku o wystąpieniu z koalicji. Nie można jednoznacznie ocenić, czy zamieszanie wokół samorządu warszawskiego faktycznie miało bezpośredni wpływ na rozpad układu rządzącego Polską, czy było jedynie wykorzystane przez unitów jako argument. Mimo usilnych prób powstrzymania Unii przed zerwaniem koalicji (m.in. prowadzenie rozmów przez obie strony i próby uzgodnienia nowego kandydata na premiera), rozpadła się ona definitywnie 6 czerwca $^{59}$.

W konsekwencji oznaczało to personalne zmiany w rządzie. Ministrów odchodzącego koalicjanta zastąpili politycy związani z AWS-em: Jarosław Bauc (finanse), Lech Kaczyński (sprawiedliwość), Jerzy Widzyk, (transport), Bronisław Komorowski (obrona narodowa), Władysław Bartoszewski (sprawy zagraniczne).

Rząd koalicyjny zawarł swe wytyczne w deklaracji politycznej, na którą składała się umowa koalicyjna oraz exposé premiera. Zawarcie umowy podczas negocjacji miało zapobiec ewentualnym problemom $\mathrm{w}$ funkcjonowaniu koalicji, co według Grzegorza Rydlewskiego stanowiło wyciągnięcie wniosków z negatywnych doświadczeń poprzedniej koalicji ${ }^{60}$.

Naturalnym zapleczem dla działań rządu stał się klub parlamentarny stworzony przez posłów komitetu wyborczego Akcji Wyborczej „Solidarność". Wygrywając wybory parlamentarne w 1997 roku, AWS wprowadziła do parlamentu 202 posłów oraz 51 senatorów. Nie oznaczało to jednak, iż $\mathrm{w}$ trakcie trwania całej III kadencji sejmu istniała jednolita struktura parlamentarna.

Początkowo Klub Parlamentarny Akcji Wyborczej „Solidarność” (utworzony 20 października 1997 roku) liczył 201 posłów. Jego przewodni-

również trzy stanowiska ministrów zadaniowych (W. Walendziak, R. Czarnecki, J. Widzy). W. Jednaka, Gabinety koalicyjne..., s. 250-252.

58 Dokument mówił o takich sprawach jak zobowiązanie do popierania projektów rządowych oraz usuwaniu z rządu osób, które podważają jego politykę. Zakładał również, iż współpraca obu klubów parlamentarnych miała być koordynowana przez międzyklubowy zespół współkierowany przez sekretarzy obu klubów. Zob. G. Rydlewski, dz. cyt., s. 56-57.

59 W. Jednaka, Gabinety koalicyjne..., s. 260.

60 G. Rydlewski, dz. cyt., s. 45. 
czącym został Marian Krzaklewski, natomiast do prezydium weszli m.in.: Czesław Bielecki (Ruch Stu), Aleksander Hall (SKL), Stanisław Iwanicki (Instytut Lecha Wałęsy), Jan Maria Jackowski (Stowarzyszenie „Rodzina Polska”), Maciej Jankowski („S”), Kazimierz Kapera (Stowarzyszenie Rodzin Katolickich), Marian Piłka (ZChN), Jacek Rybicki („,"), Ludwik Dorn (PC) ${ }^{61}$.

Liczba członków Klubu spadała przez całą kadencję z powodu secesji osób związanych z ugrupowaniami wchodzącymi w skład koalicji wyborczej. W końcu - po odejściu 1/3 polityków - zostało 134 posłów ${ }^{62}$. Pierwsze wystąpienia (nie licząc pojedynczego przypadku Ludwika Dorna z 11 listopada 1997 roku) miały miejsce 15 czerwca 1998 roku, kiedy to Klub opuściła grupa ośmiu posłów związanych z Adamem Słomką, która następnie uformowała Koło Poselskie Konfederacji Polski Niepodległej (grupa ta została ostatecznie usunięta z Akcji w lipcu 1998, kiedy to jej członkowie odmówili poparcia dla rządu w sprawie reformy administracyjnej ${ }^{63}$.

Kolejna - tym razem sześcioosobowa - grupa secesjonistów wystąpiła z klubu 23 lipca 1998 roku, zakładając następnie we wrześniu 1998 roku Poselskie Nasze Koło (od 25 września Koło Poselskie Porozumienie Polskie). W tych dwu grupach oraz w Kole Parlamentarnego Ruchu Odbudowy Polski (później Ruchu Odbudowy Polski - Porozumienia Centrum) nastąpiły „przetasowania", których efektem były nowe koła poselskie. I tak, 23 grudnia 1999 roku powstało trzyosobowe Koło Polskiej Racji Stanu, które 12 lipca połączyło się z Kołem Parlamentarnym Konfederacji Polski Niepodległej, tworząc Koło Parlamentarne Koalicja dla Polski (8 osób). Jednak po częściowym rozpadzie, przekształciło się ono 2 kwietnia 2001 roku w Koło Parlamentarne Alternatywa (6 osób) ${ }^{64}$.

Kolejna fala procesu „kurczenia się” Klubu Parlamentarnego AWS-u nastąpiła w schyłkowym okresie III kadencji. Co prawda, w międzyczasie grono poselskie Akcji zmniejszyło się o 12 osób, jednak prawdziwy rozpad miał miejsce wiosną oraz latem 2001 roku. W marcu, kosztem klubu AWS-u powstał 17-osobowy (później powiększony o jedną osobę) Klub Parlamentarny Stronnictwa Konserwatywno-Ludowego, natomiast w lipcu 18-osobowy Klub Parlamentarny Prawa i Sprawiedliwości ${ }^{65}$.

61 W. Załuska, Prezydium przewodniczacego, „Gazeta Wyborcza” 1997, nr 243, s. 4.

${ }^{62}$ Sejm Rzeczypospolitej Polskiej - III kadencja: Zgromadzenie Narodowe: informacje o działalności (20 października 1997 r. - 18 października 2001 r.), red. I. Chodyra, M. Iżykowska, Warszawa 2002, s. 12.

63 A. Dudek, Historia polityczna..., s. 366.

64 Sejm Rzeczypospolitej Polskiej - III kadencja: Zgromadzenie Narodowe: informacje o działalności (20 października 1997 r. - 18 października 2001 r.), s. 282-299.

65 Tamże. 


\section{Defragmentacja Akcji Wyborczej „Solidarność”}

Prowadząc badania nad funkcjonowaniem partii politycznych, łatwo określić początek istnienia danego ugrupowania, każde bowiem musi zostać zarejestrowane. Problem pojawia się przy zakończeniu życia tworu politycznego. Niekiedy bowiem zdarza się, i tak było w przypadku Akcji Wyborczej „Solidarność", iż ugrupowanie formalnie istnieje, a tak naprawdę przestaje funkcjonować bądź to całkowicie, bądź też w nominalnym kształcie. Niemożliwym wydaje się podanie konkretnej daty rozpadu Akcji. W mojej opinii, można jednak ukazać pewien proces, który nazwałbym „dezintegracją Akcji Wyborczej „Solidarność”. Za początek całego procesu uznałbym dwa wydarzenia: rozpad koalicji AWS-UW oraz udział Mariana Krzaklewskiego, przewodniczącego Akcji, w wyborach prezydenckich w roku 2000. Nie mam tu na myśli samego startu, ale raczej polityczną atmosferę wokół tej inicjatywy związaną z nieustępliwością kandydata oraz konsekwencje polityczne, jakie ów start przyniósł. Można, co prawda, wskazać również na różnice ideologiczne w ramach Akcji, jednak ta droga, jak sądzę, groziłaby doszukiwaniem się przyczyn rozpadu już w samej istocie ugrupowania pod przewodnictwem Krzaklewskiego. Dwa wskazane przeze mnie wydarzenia na pewno nie stanowiły źródła kryzysu wewnątrz Akcji, ale sprawiły, że istniejące różnice zdań zaczęły stawać się wyraźniejsze i coraz trudniej było łagodzić konflikty. Znaczenie miała również struktura Akcji. Dominacja czterech dużych partii była dla niej niebezpieczna, gdyż silniejsze ugrupowania zaczęły dbać o swoje interesy, swoje cele programowe, nie zaś o interesy „całości”. „Rozdrobniona" AWS była traktowana przez słabe i małe ugrupowania jako szansa na przyszłość i dlatego też respektowały one jej silne przywództwo ${ }^{66}$.

Postawa Mariana Krzaklewskiego, który wstrzymywał się z jednoznaczną deklaracją co do startu w wyborach prezydenckich, spowodowała, iż trwająca kilka miesięcy debata na temat prawyborów doprowadziła do pogłębienia podziałów wewnątrz koalicyjnego ugrupowania. Dopiero podczas II Zjazdu RS AWS-u, w kwietniu 2000 roku jej przewodniczący ogłosił kandydowanie w wyborach prezydenckich. Decyzję tę poparły wszystkie stronnictwa wchodzące w skład Akcji, oprócz SKL-u ${ }^{67}$. Ugrupowanie ewolucyjnych konserwatystów było już wówczas największym przeciwnikiem Krzaklewskiego. SKL forsował projekt prawyborów w celu wyłonienia jednego kandy-

66 W. Załuska, Rozmawiali jak działać, „Gazeta Wyborcza” 1999, nr 43, s. 4.

${ }^{67}$ Postawa SKL-u - wyrażona przez Radę Polityczną ugrupowania - była dość oryginalna, gdyż nie popierała startu Krzaklewskiego w wyborach, a jednocześnie mówiła o dostosowaniu się do woli władz AWS-u. Był to zapewne wynik niejednolitego poglądu członków SKL-u wobec strategii działania wewnątrz AWS-u., W Załuska Takjak nie, nie jak tak, „Gazeta Wyborcza" 2000, nr 118, s. 4. 
data Akcji na prezydenta. Jednocześnie coraz częściej padało nazwisko Macieja Płażyńskiego jako ewentualnego rywala dla Krzaklewskiego. Relacje przewodniczącego AWS-u z SKL-em uległy pogorszeniu wraz z wyborem na prezesa Stronnictwa Konserwatywno-Liberalnego Jana Rokity podczas zjazdu partii w marcu $2000 \mathrm{roku}^{68}$.

Rozpad koalicji oraz spadające notowania AWS-u nie tworzyły pozytywnej atmosfery dla dalszego jednoczenia się ugrupowań. Przegrana Mariana Krzaklewskiego w wyborach prezydenckich tylko pogorszyła i tak napiętą wówczas atmosferę polityczną.

Pierwszym wyrazem narastającego kryzysu było powołanie komitetu porozumiewawczego wewnątrz Akcji (zwanego Komisją Odnowy AWS-u) dnia 17 października 2000 roku przez prezesów PPChD, SKL-u, ZChN-u, a także Macieja Płażyńskiego oraz Wiesława Chrzanowskiego. Nowy ruch zmierzał do ograniczenia roli związku zawodowego w Akcji oraz do zmiany na czele AWS- $u^{69}$. Zamiast tego jednak, powstanie Komisji Odnowy AWS-u rozpoczęło okres wewnętrznych rozgrywek i przepychanek między członkami z Akcji Wyborczej „Solidarność”. Widocznym wyrazem napięć w Akcji było utworzenie 12 listopada 2000 roku przez Marszałka Sejmu Macieja Płażyńskiego (wraz z liderami PPChD i SKL-u) Federacji AWS. Środowisko skupione wokół Marszałka, mimo iż wewnętrznie również niespójne ${ }^{70}$, doprowadziło do zmian w organizacji Akcji.

Porozumienie, jakie zawarły 23 grudnia 2000 roku SKL, ZChN, PPChD, RS AWS oraz NSZZ „Solidarność”, miało sprzyjać zakończeniu sporów. Dokonano szeregu zmian. AWS przekształcono w federację, zaś po wyborach parlamentarnych 2001 roku, w których wszystkie wymienione wyżej partie postanowiły wystartować jako koalicja, miała się ona przekształcić w jednolite ugrupowanie. Przewodniczącym Federacji został Jerzy Buzek, zaś jego zastępcą - Maciej Płażyński. Federacją AWS kierować miał ośmioosobowy zarząd składający się z: czterech osób wyznaczonych przez PPChD, SKL i ZChN oraz czterech przez RS AWS i „S”. Rada Krajowa AWS-u zmieniła swoje obli-

68 A. Dudek, Historia polityczna..., s. 391-392; M. D. Zdort, Spór Krzaklewskiego z Płażyńskim, „Rzeczpospolita” 2000, nr 67, s. 1.

69 Zob. W. Załuska, W. Sandecki, Poziomka w AWS, „Gazeta Wyborcza” 2000, nr 244, s. 6. W AWS-ie pojawiło się kilka koncepcji dotyczących przyszłości ugrupowania. Oprócz powstałej Komisji Odnowy oraz idei utworzenia jednego ugrupowania, był to także projekt współpracy z UW, zob. W. Załuska, Nowa geografia Akcji, „Gazeta Wyborcza” 2000, nr 253, s. 4.

70 PPChD i SKL różniły poglądy na temat przyszłości federacji, strategii współpracy ze związkowcami oraz funkcjonowania rządu Jerzego Buzka. Zob. Wojciech Załuska, Federacja Płażyńskiego, „Gazeta Wyborcza” 2000, nr 269, s. 3; tenże, Federacja o Federacji, „Gazeta Wyborcza" 2000, nr 285, s. 5. 
cze. Do liczącego 100 osób organu trzy partie (PPChD, SKL i ZChN) mogły delegować 51 przedstawicieli, zaś RS AWS i „S”-49. Decyzje miały być podejmowane większością głosów, co oznaczało osłabienie strony związkowej ${ }^{71}$.

Wydawać by się mogło, iż koniec roku 2000 przyniósł spokój w szeregach Akcji. Nic bardziej mylnego. Dobry wynik Andrzeja Olechowskiego w wyborach prezydenckich, przy jednoczesnej porażce Mariana Krzaklewskiego, spowodował poruszenie w polskiej centroprawicy. 10 stycznia 2001 roku z inicjatywy Andrzeja Olechowskiego, Donalda Tuska (opuszczającego Unię Wolności) oraz Macieja Płażyńskiego ogłoszono decyzję o budowie nowego ugrupowania politycznego: Platformy Obywatelskiej ${ }^{72}$. Mimo iż docelowym elektoratem PO byli wyborcy UW, a nie AWS-u, to fakt, iż Płażyński pojawił się w szeregach Platformy, nie wróżył dla Akcji niczego dobrego.

Odejście lidera „reformatorów” z Akcji Wyborczej „Solidarność” wywołało w jej szeregach niemałe zamieszanie: rozpoczęło faktyczną dezintegrację ugrupowania. Dotychczasowi współpracownicy Płażyńskiego z Federacji AWS, czyli SKL-u, we własnym gronie nie mogli osiągnąć zgody co do przyszłości własnego ugrupowania. Mogło ono funkcjonować nadal jako część AWS-u lub dokonać wolty i podjąć współpracę z nowym tworem politycznym. Różnice zdań widoczne były nie tylko wśród „zwykłych” członków ugrupowania, ale również w samych władzach Stronnictwa, gdzie prezes Jan Rokita opowiadał się za pozostaniem w Akcji, natomiast Aleksander Hall (szef Rady Politycznej) był zwolennikiem drugiego rozwiązania ${ }^{73}$.

Problem został rozstrzygnięty przez Radę Polityczną ugrupowania 27 stycznia 2001 roku, kiedy to podczas spotkania głównego organu partii poprzez głosowanie podjęto decyzję o pozostaniu w strukturach Akcji Wyborczej „Solidarność”. Burzliwa dyskusja w trakcie obrad oraz minimalna różnica głosów uwidoczniły tylko podział i nie wróżyły ugrupowaniu niczego dobrego ${ }^{74}$. Po okresie niespełna dwóch miesięcy, 17 marca, odbyło się kolejne głosowanie w ramach nadzwyczajnego zjazdu Rady Politycznej. Tym razem podjęto decyzję o wystąpieniu Stronnictwa z Akcji i podjęciu współpracy z Platformą Obywatelską. Spowodowało to jednak faktyczny rozłam ugrupowania. W AWS-ie pozostała grupa posłów SKL-u, między innymi: Mirosław Styczeń, Wiesław Walendziak, Kazimierz Ujazdowski i Adam Bielan ${ }^{75}$. Warto

\footnotetext{
71 D. Wielowiejska, Chęć jedności, „Gazeta Wyborcza” 2000, nr 300, s. 3.

72 A. Dudek, Historia polityczna..., s. 402.

73 Zob.: W. Załuska, Rozdarte SKL, „Gazeta Wyborcza” 2001, nr 12, s. 6; tenże, Z AWS nic nie będzie, rozmowa z Aleksandrem Hallem, „Gazeta Wyborcza” 2001, nr 10, s. 5; tenże, Myślę o nich ciepło, ale sukcesu nie będzie, rozmowa z Janem M. Rokita, ,Gazeta Wyborcza” 2001, nr 12, s. 6.

74 Zob. tenże, Przepołowieni, „Gazeta Wyborcza” 2001, nr 24, s. 5.

75 Zob. M.D. Zdort, SKL odchodzi z AWS, „Rzeczpospolita” 2001, nr 66, s. 6.
} 
zauważyć, iż decyzja o opuszczeniu szeregów Akcji miała miejsce dzień po kongresie Akcji Wyborczej „Solidarność”, podczas którego podjęto próbę odbudowy ugrupowania.

Niejednolite wyjście SKL-u z AWS-u uruchomiło kolejne ruchy w obrębie ugrupowań polskiej centroprawicy. Konserwatyści, którzy sprzeciwiali się współpracy z PO, znaleźli wspólny język z przedstawicielem Ligi Republikańskiej - Mariuszem Kamińskim oraz secesjonistami, członkami ZChN-u, którzy z kolei nie zgadzali się na politykę swojej partii. Tacy politycy jak: Marian Piłka, Tomasz Szyszko, Michał Kamiński, Artur Zawisza czy Kazimierz Marcinkiewicz, niepodzielający polityki własnego ugrupowania, już od wyborów prezydenckich poszukiwali wyjścia z tej sytuacji ${ }^{76}$. Wyrazem tego było powołanie 26 marca 2001 roku nowego ugrupowania o nazwie Przymierze Prawicy ${ }^{77}$.

W tym samym czasie, gdy powstawało nowe ugrupowanie o charakterze konserwatywnym, pierwsze kroki stawiały lokalne komitety społeczne Prawa i Sprawiedliwości ${ }^{78}$ zawdzięczające swoją popularność osobie Lecha Kaczyńskiego, ówczesnego ministra sprawiedliwości. Inicjatorami komitetów byli dawni działacze Porozumienia Centrum oraz Stowarzyszeń: Na Rzecz Zrównoważonego Rozwoju oraz Nowe Państwo. 13 czerwca 2001 roku zarejestrowano również partię o nazwie Prawo i Sprawiedliwośćc7.

Początkowo, politycy obu powstałych w marcu środowisk - PiS-u oraz Przymierza Prawicy - wyrażali chęć startu w wyborach z jednej listy wraz z Akcją, pod warunkiem jednak, że zostaną dokonane w niej zmiany. Ostatecznie, w maju podjęto decyzję o starcie Prawa i Sprawiedliwości z własnych list w wyborach parlamentarnych ${ }^{80}$. Nie był to jednak start samodzielny, gdyż od końca marca trwały rozmowy pomiędzy PiS-em i PP na temat wspólnych list wyborczych, zakończone podpisaniem 23 maja 2001 roku porozumienia regulującego tę kwestię ${ }^{81}$. Przymierze ostatecznie opuściło szeregi Akcji po zamieszaniu związanym z dymisją Lecha Kaczyńskiego.

Osłabiona AWS otrzymał jeszcze jeden cios, a mianowicie: w maju 2001 roku decyzję o wycofaniu się z AWS podjęła Komisja Krajowa NSZZ „Solidarność". W ramach struktury federacyjnej pozostały jedynie RS AWS, ZChN

\footnotetext{
Tenże, Dalsze przetasowania w AWS, „Rzeczpospolita” 2001, nr 28, s. 3.

K. A. Paszkiewicz, Przymierze Prawicy, w: Partie i koalicje polityczne w Polsce, s. 118.

78 Pierwszy Komitet Społeczny Prawa i Sprawiedliwości powstał w Białymstoku 22 III 2001 roku, krajowy zaś 26 kwietnia 2001 roku.

K. A. Paszkiewicz, Prawo i Sprawiedliwość, w: Partie i koalicje polityczne w Polsce, s. 112.

M. D. Zdort, Dwie prawice, „Rzeczpospolita” 2001, nr 117, s. 3.

Tenże, Bracia Kaczyńscy ruszaja do Sejmu, „Rzeczpospolita” 2001, nr 134, s. 3.
} 
oraz PPChD, które razem wystartowały w koalicyjnym komitecie wyborczym: AWS Prawicy.

\section{Prawica rozbita}

Akcja Wyborcza „Solidarność” jako zjednoczona centroprawica wygrała wybory parlamentarne, była największym klubem parlamentarnym oraz dominującym komponentem rządu koalicyjnego. Posiadała także bardzo duży kapitał w postaci poparcia społecznego. Jednak Akcja szybko zaprzepaściła szansę wpisania się w krajobraz polskiego systemu partyjnego na stałe.

Podstawową przyczyną jednoczenia się ugrupowań była chęć powrotu do wielkiej polityki. AWS zrealizowała ten plan już na początku swego istnienia. Szybko zatem powróciły problemy z politycznymi aspiracjami poszczególnych liderów, co przekładało się na prace rządu, niemającego często poparcia dla swoich inicjatyw w zapleczu parlamentarnym. Dodatkowo, wewnętrzne konflikty w koalicji wyborczej nie tworzyły pozytywnego jej obrazu w społeczeństwie.

Defragmentacja Akcji rozpoczęła się w zasadzie od samego początku jej obecności w rządzie, kiedy to pojawiły się konflikty natury programowej ze środowiskiem Adama Słomki. Rozpad AWS-u przebiegał, co prawda, podczas kadencji, ale ostatecznie dokonał się w roku 2001, a właściwie jeszcze przed wyborami parlamentarnymi. Ostatecznie historia - kluczowej dla polskiej prawicy - koalicji wyborczej zakończyła się wraz z upadkiem Akcji Wyborczej „Solidarność” Prawicy, która poniosła porażkę wyborczą. Warto jednak zauważyć, iż AWSP, startując jako jedno ugrupowanie, przekroczyłaby prób wyborczy, gdyż uzyskała wynik 5,6\%, zaś partie, które powstały kosztem rozpadu Akcji, odniosły umiarkowany sukces, otrzymując: PO - 12,68\% oraz PiS - 9,5\% głosów $^{82}$ (łącznie wynik był zatem bliski 30\%).

Analizując ewolucję AWS-u, warto zwrócić uwagę na pozytywne aspekty funkcjonowania tejże koalicji, jakimi były procesy jednoczenia się nurtów politycznych w jej wnętrzu. Plusem jest również fakt, iż ostatecznie na „zgliszczach” AWS-u powstały dwa silne ugrupowania PO oraz PiS, co jak pokazały wybory w pierwszej dekadzie XXI wieku - pozwoliło ustabilizować scenę polityczną w Polsce.

Nie można jednak mówić o Akcji Wyborczej „Solidarność”, nie próbując wyjaśnić przyczyn jej rozpadu. Wydaje się, że różnice ideowe okazały się zbyt silne, aby łączyć kilka ugrupowań w jedną całość. Powstałe silne nurty: związkowy, narodowy i konserwatywno-liberalny oraz trochę słabszy chrze-

82 Strona internetowa Państwowej Komisji Wyborczej: [http://www.pkw. gov.pl/katalog/ 2469.html; dostęp: 2.02.2009]. 
ścijańsko-demokratyczny nie były w stanie ze sobą współpracować na tyle, aby tworzyć jednolitą partię. Podstawa programowa, czyli Karta AWS-u, pozwalała na współpracę różnorodnych ugrupowań w fazie przedwyborczej. Gdy jednak przyszło realizować program w postaci prac parlamentarnych oraz rządowych, ujawnily się podziały ideowe, które okazały się zbyt silne. Zresztą, trudno sobie wyobrazić jednolity program polityczny formacji, która zrzeszać miałaby zarówno związkowców, jak również liberalnych gospodarczo członków SKL-u, konserwatywnych obyczajowo polityków ZChN-u oraz liberalnych światopoglądowo Ruchu Stu. Konflikty były zatem tylko kwestią czasu.

Ostatecznie, należy powiedzieć, iż AWS okazała się zaprzepaszczoną szansą. Być może jednak jej rozpad to cena, jaką musiała zapłacić polska prawica, aby przejść przez proces instytucjonalizacji. W rezultacie, dzięki przekształceniom AWS-u udało się skrystalizować nurty ideowe, dotąd rozproszone na drobne ugrupowania. Akcja nie zaniknęła w ogóle, ale rozpadła się na kilka „elementów”. Łatwo zauważyć, iż był to krok do przodu.

Losy AWS-u ukazały, iż pomysł budowy jednolitego, silnego ugrupowania centroprawicowego był odpowiedni dla ówczesnej sytuacji politycznej. Co więcej, był on oczekiwany przez wyborców. Jednak trwałe istnienie szerokiego nurtu ideowego okazało się niemożliwe, gdyż nie zadowalał on ambicji wszystkich polityków prawicowych. 


\section{Abstract}

This article considers the phenomenon of the most significant political party in 1990s in Poland, the Akcja Wyborcza Solidarność (Solidarity Electoral Action). The author outlines the process of its forming, activity and, finally, its termination.

Akcja Wyborcza Solidarność was formed on July $11^{\text {th }}, 1996$ as a coalition of over forty parties. The main goal of this union was to participate and eventually win in the forthcoming parliamentary elections.

The activity of Akcja Wyborcza Solidarność can be divided into two periods. The first one was connected with forming of four strong inner groups of Akcja Wyborcza Solidarność (Solidarity Electoral Action), while in the second period occurred the separation of conservative group.

The author of the article focuses on the main factors that finally caused the termination of Akcja Wyborcza Solidarność. It seems that the ideological differences were too intense, and further functioning of this peculiar coalition appeared to be impossible. Furthermore, the personal conflicts between Akcja Wyborcza Solidarność members had also impact on incapacity to forming a strong coalition. 